\title{
IDE DASAR DOUBLE TRACK SYSTEM : SANKSI PIDANA DAN TINDAKAN SEBAGAI SISTEM PEMIDANAAN TERHADAP PELAKU KEJAHATAN PENYALAHGUNAAN NARKOTIKA
}

\author{
Merry Natalia Sinaga \\ Fakultas Hukum Universitas Simalungun \\ Sinaga.merry@yahoo.com
}

\begin{abstract}
Abstrak
Penyalahgunaan Narkotika merupakan bahaya yang dapat menghambat kemajuan bangsa Indonesia dalam melaksanakan pembangunan di setiap sektor kehidupan. Dimana kita ketahui bahwa Indonesia pada dekade 70-an belum lagi menjadi daerah yang menggiurkan bagi pemasaran narkotika. Pada saat itu, negeri ini hanya merupakan wilayah transit bagi barang-barang haram yang akan dikirim ke Australia atau ke Negara Asia Pasifik lainnya. Namun dua dasa warsa kemudian, Indonesia sudah menjadi pasar yang menggiurkan bagi para pengedar narkotika. Bahkan disebut-sebut menjadi produsen barang yang bisa membuat perasaan melayang-layang itu. Permasalahan yang dihadapi saat ini adalah yang berkaitan dengan narkotika adalah bahwa Sumatera Utara menempati ranking ketiga setelah DKI Jakarta dan Kalimantan Timur dalam tingkat pemakai narkoba. Menyiapkan pusat rehabilitasi khususnya bagi pelaku tindak pidana narkoba adalah merupakan solusinya. Mereka membutuhkan proses penyembuhan dari ketergantungan obat terlarang tersebut. Mempenjarakan bukanlah solusi yang tepat bagi permasalahan ini, menahan tetapi juga melakukan terapi medis barulah akan berhasil. Bukan rahasia lagi banyak pemakai obat yang di Lembaga Pemasyarakatan tetapi masih ketergantungan obat. Ini disebabkan mereka hanya ditahan secara fisik tetapi penyakitnya belum sembuh. Mereka itu butuh pengobatan yang selama ini tidak maksimal didapatkan.
\end{abstract}

Kata kunci: double track sistem, penyalahgunaan, narkotika, penyembuhan

\begin{abstract}
Narcotics abuse and circulation is a threat that can hinder the progress of Indonesia in carrying out the development in every sector of life. As we have been aware of that in the 70s decade, Indonesia had not become a lucrative target for the marketing of narcotics. At that time, the country was only considered as a transit area for illegal goods before they were shipped to Australia and other Asia pacific regions. But, two decades later, Indonesia has shifted into a money-spinning market for narcotics dealers even touted as a major producer of these illegal goods. Moreover, the problem faced today is also related to the fact that North Sumatra is on the third rank of this narcotics circulation and the level of drug users after Jakarta and East Kalimantan. Setting up a rehabilitation center especially for drug offenders is a solution for the victims need the healing process of the drug addiction. Imprisoning is not the right solution for overcoming this problem if it is not supported with the medical therapy. The fact that many of the inmates or drug users who still supplied and get addicted in the correctional institution is no longer a surprise. This is because they are only physically detained but the addiction has not been healed, thus, they need treatments that have not been maximally obtained.
\end{abstract}


Keywords: double track system, narcotics abuse, rehabilitation centre, treatment and healing.

\section{PENDAHULUAN}

Narkotika di satu sisi merupakan obat dan bahan yang bermanfaat di bidang pengobatan atau pelayanan kesehatan dan pengembangan ilmu pengetahuan, namun di lain pihak Narkotika dapat menimbulkan ketergantungan apabila disalah gunakan, sehingga dapat mengakibatkan gangguan fisik, mental, sosial, keamanan dan ketertiban masyarakat yang akhirnya menganggu ketahanan nasional maupun internasional. Penyalahgunaan Narkotika merupakan bahaya yang dapat menghambat kemajuan bangsa Indonesia dalam melaksanakan pembangunan di setiap sektor kehidupan. Dimana kita ketahui bahwa Indonesia pada dekade 70-an belum lagi menjadi daerah yang menggiurkan bagi pemasaran narkotika. Pada saat itu, negeri ini hanya merupakan wilayah transit bagi barang-barang haram yang akan dikirim ke Australia atau ke Negara Asia Pasifik lainnya. Namun dua dasa warsa kemudian, Indonesia sudah menjadi pasar yang menggiurkan bagi para pengedar narkotika. Bahkan disebut-sebut menjadi produsen barang yang bisa membuat perasaan melayang-layang itu.

Permasalahan yang dihadapi saat ini adalah yang berkaitan dengan narkotika adalah bahwa Sumatera Utara menempati ranking ketiga setelah DKI Jakarta dan Kalimantan Timur dalam tingkat pemakai narkoba. PBB sejak tahun 1987 menetapkan 26 Juni sebagai hari Madat sedunia oleh International Day Againts Drug.Badan Narkotika Nasional (BNN)menyebutkan narkoba tiap tahun membunuh 15.000 nyawa anak bangsa.Ironisnya jumlah pengguna narkoba justru bertambah .Saat ini terdapat sekitar 3,2 juta pengguna narkoba.Jumlah jelas menguntungkan para produsen atau bandar.Berdasarkan riset YCAB (Yayasan Cinta Anak Bangsa),sebuah yayasan yang concern terhadap bahaya narkoba, jumlah pengguna narkoba naik dari 8 \% pada tahun 2001 menjadi $11 \%$ pada tahun 2006. Penegakan hukum terhadap tindak pidana narkotika telah banyak dilakukan oleh aparat penegakan hukum dan telah banyak mendapatkan putusan hakim di sidang pengadilan.Penegakan hukum ini diharapkan mampu sebagai faktor penangkal terhadap merebaknya peredaran perdagangan narkoba, tapi dalam kenyataan justru semakin intensif dilakukan penegakan hukum, semakin meningkat pula peredaran perdagangan.

Penyalahgunaan narkotika di Indonesia sudah sampai ketingkat yang sangat mengkhawatirkan. Menurut Menhuk dan HAM Amir Syamsuddin.Berdasarkan data Kemenhuk dan HAM pada tahun 2011 tercatat penggagalan 98 kasus penyeludupan narkoba di dalam Lembaga Pemasyarakatan. Sedangkan tahun 2012 baru mengungkap 12 kasus narkoba. Permasalahan yang terjadi bahwa Lembaga pemasyarakatan di Indonesia adalah salah satu pasar 
bagi pengedar narkoba. Pemakai narkoba banyak di tahan di Lembaga Pemasyarakatan mereka rata-rata memiliki uang.Hal ini menyebabkannya seringkali mereka belum dalam kondisi sembuh tapi masih ketergantungan pada narkoba. Permasalahan yang terjadi saat ini kita menganggap kalau pemakai narkoba itu memiliki karakter seperti penjahat biasa sehingga bisa di campur dengan narapidana lainnya. Padahal mereka yang memakai narkoba adalah dalam kondisi ketergantungan obat yang sakit secara fisik dan psikologis.

Mereka membutuhkan rehabilitasi medis untuk memulihkan kondisinya. Saat dimasukkan Lembaga Pemasyarakatan tanpa ada terapi medis maka ini tidaklah menyelesaikan masalah mereka karena mereka dalam kondisi ketergantungan obat. Upaya untuk melakukan Sidak pada pengguna narkotika di Lembaga Pemasyarakatan hanya akan menghentikan kegiatan ini sementara. Akar permasalahannya justru pada adanya permintaan narkoba yang cukup besar dan adanya penawaran untuk itu sehingga terjadi transaksi.

Mereka di penjara dalam posisi ketergantungan obat dan segala cara akan dilakukan untuk mendapatkan obat. Selama ini mereka tidak mendapatkan terapi di Lembaga Pemasyarakatan untuk mengurangi ketergantungan obatnya sehingga kondisinya masih tetap sakit. Ditambah lagi dengan kondisi penjara di Indonesia yang sebagian besar sudah kelebihan kapasitas. Kondisi ini dapat memperparah keadaannya, beberapa Narapidana yang tadinya tidak terlibat jaringan narkoba dapat saja menjadi pengedar. Contohnya Narapidana Curanmor karena berinteraksi dengan para narkoba bisa saja menjadi pengedar berikutnya bahkan residivis, ini justru dapat memunculkan masalah baru lagi. Menyiapkan pusat rehabilitasi khususnya bagi pelaku tindak pidana narkoba adalah merupakan solusinya. Mereka membutuhkan proses penyembuhan dari ketergantungan obat terlarang tersebut. Mempenjarakan bukanlah solusi yang tepat bagi permasalahan ini, menahan tetapi juga melakukan terapi medis barulah akan berhasil. Bukan rahasia lagi banyak pemakai obat yang di Lembaga Pemasyarakatan tetapi masih ketergantungan obat. Ini disebabkan mereka hanya ditahan secara fisik tetapi penyakitnya belum sembuh. Mereka itu butuh pengobatan yang selama ini tidak maksimal didapatkan.

Mereka yang ada di dalam Lembaga Pemasyarakatan dalam kondisi ketergantungan obat sebaiknya memang mendapatkan terapi medis yang tepat dan direhabilitasi sehingga bukannya berada pada lingkungan sesama Narapidana yang masih ketergantungan obat seperti sekarang ini. Kondisi ini justru dapat memperparah keadaan ketergantungan mereka pada obat. Pembangunan pusat rehabilitasi berbasis Lembaga Pemasyarakatan sangat diperlukan sehingga penanganan dari pelaku narkoba dapat penanganan yang tepat.

\subsection{Rumusan Masalah}

Bagaimanakah sanksi pidana dan tindana di dalam sistem 
pemidanaan (ide double track sistem) dilakukan terhadap pelaku tindak pidana narkotika?

\section{METODE}

\subsection{Jenis Penelitian}

Penelitian Hukum yang dilakukan adalah Penelitian Hukum Yuridis Normatif yaitu pendekatan yang dilakukan berdasarkan kepada hukum utama dengan dengan cara menelaah teori-teori , konsep-konsep , asas-asas hukum serta peraturan perundang-undangan yang berkaitan dengan penelitian ini.

\subsection{Sumber Data}

Bahan hukum yang diperoleh dari Data Sekunder yaitu bersumber dari Penelitian Kepustakaan (Library Research).

\subsection{Teknik Pengumpulan Data}

Teknik yang digunakan dalam penelitian ini adalah teknik studi dokumen yaitu data yang diperoleh dari Kepustakaan yang relevan .

\subsection{Teknik Analisis}

Keseluruhan data yang telah didapat akan dianalisis secara Kualitatif atau dikenal dengan Analisis Deskriftif Kualitatif. Dimana keseluruhan data yang terkumpul akan dianalisis secara sistematis .

\section{HASIL DAN PEMBAHASAN}

Pidana penjara dari arti sifatnya adalah menghilangkan dan atau membatasi kemerdekaan bergerak,dalam arti menempatkan Terpidana dalam suatu tempat (Lembaga Pemasyarakatan)dimana Terpidana tidak bebas untuk keluar masuk dan didalamnya wajib untuk tunduk mentaati dan menjalankan semua peraturan tata tertib yang berlaku.Antara Pidana Penjara dan Pidana Kurungan tampaknya sama, akan tetapi kedua jenis pidana ini sesungguhnya berbeda jauh. Penjara atau istilah masa kini diindonesia pemasyarakatan " merupakan penemuan baru yang mulai berkembang secara luas 300 tahun terakhir ini. Ia merupakan bagian dari perkembangan sistem pemidanaan dari masa ke masa. Dewasa ini pemenjaraan dipandang sebagai bentuk pidana yang bertujuan untuk memperbaiki penjahat dan disebut reformasi sistem pemidanaan yang berjalan kearah yang lebih rasional. Berbeda dengan pandangan lama yang bertujuan menyingkirkan penjahat dari masyarakat.

Sebab-sebab perubahan ini ialah karena perkembangan ekonomi,perkembangan kearah yang manusiawi dan munculnya pandangan yang lebih sekuler,timbulnya konsep-konsep baru mengenai hakikat manusia dan masyarakat. Walaupun sekarang dikatakan sistem pemidanaan menuju kearah rehabilitasi penjahat,sifat pidana sendiri sebagai sanksi kepada pelanggar hukum tidak mungkin disingkirkan. Sistem pemidanaan terus dipermasalahkan oleh para ahli,sampai kini pun belum pernah ada yang memuaskan secara sempurna.Penjurusan pandangan akhirnya terjadi pada permulaan abad ke-19 dengan munculnya dua pandangan yang saling bertentangan tentang filsafat pemidanaan.

Ide Sahardjo tersebut dijabarkan dalam Komperensi Direktur Penjara seluruh Indonesia pada tanggal 27 April 1964 di 
Lembang Bandung. Pada konferensi itulah dimulai tekad untuk memperbaiki sistem pembinaan narapidana dan anak didik. Karena Konferensi Direktur-Direktur Penjara di Lembang Pemasyarakatan pada tanggal 27 April - 7 Mei 1964 menerima sistem pemasyarakatan tersebut, maka pada tanggal 27 April diambil sebagai Hari Pemasyarakatan. Sejak tahun 1968 dipakai istilah Kantor Direktorat Jenderal bina warga, narapidana menjadi Tuna Warga. Pada tahun 1976 Kantor Direktorat Jenderal Bina Tuna Warga berubah menjadi Kantor Direktorat Jenderal Pemasyarakatan sehingga tuna warga berubah kembali menjadi istilah narapidana. Untuk saat sekarang ini hambatan dalam rangka pembinaan bagi narapidana terutama dari segi keuangan yang sangat terbatas, diikuti oleh prasarana baik fisik berupa gedung dan perlengkapan maupun pendidikan para pelaksana pemasyarakatan,disamping sikap masyarakat itu sendiri yang sulit meninggalkan sifat pembalasan daripada pidana menjadi reformasi.

Pidana penjara dari arti sifatnya adalah menghilangkan dan atau membatasi kemerdekaan bergerak,dalam arti menempatkan Terpidana dalam suatu tempat (Lembaga Pemasyarakatan)dimana Terpidana tidak bebas untuk keluar masuk dan didalamnya wajib untuk tunduk mentaati dan menjalankan semua peraturan tata tertib yang berlaku.Antara Pidana Penjara dan Pidana Kurungan tampaknya sama, akan tetapi kedua jenis pidana ini sesungguhnya berbeda jauh. Penjara atau istilah masa kini di Indonesia "Pemasyarakatan"merupakan penemuan baru yang mulai berkembang secara luas 300 tahun terakhir ini.Ia merupakan bagian dari perkembangan sistem pemidanaan dari masa ke masa.

Dewasa ini pemenjaraan dipandang sebagai bentuk pidana yang bertujuan untuk memperbaiki penjahat dan disebut reformasi sistem pemidanaan yang berjalan kearah yang lebih rasional.Berbeda dengan pandangan lama yang bertujuan menyingkirkan penjahat dari masyarakat. Sebab-sebab perubahan ini ialah karena perkembangan onomi,perkembangan kearah yang manusiawi dan munculnya pandangan yang lebih sekuler,timbulnya konsep-konsep baru mengenai hakikat manusia dan masyarakat. Walaupun sekarang dikatakan sistem pemidanaan menuju kearah rehabilitasi penjahat,sifat pidana sendiri sebagai sanksi kepada pelanggar hukum tidak mungkin disingkirkan. Menurut A.A.L. Minkenhof kepada Sudarto di Nederlands, pengalihan sistem pemenjaraan ke sistem bekerja di luar Penjara dan Pengawasan jangan sampai menyenangkan Terpidana,karena pidana itu tetap merupakan hal yang tidak menyenangkan.

Pada akhir abad ke-18 sistem pemidanaan yang lebih modren telah dikembangkan dasar-dasarnya oleh John Howard di Inggris. Ia berkeliling ke seluruh Eropah untuk meneliti metode - metode perbaikan sistem pemidanaan. Keadaan penjara pada masa itu memang sangat menyedihkan. Penjara Bastile yang termashur didalam sejarah sebagai sumber meledaknya revolusi Perancis dengan penyerbuan oleh masyarakat terhadap penjara itu. 
Keadaan penjara pada masa itu telah mengetuk hati John Howard untuk membuat konsep sistem pemidanaan dimana narapidana dipisahkan satu sama yang lain dan dipekerjakan secara teratur. Usaha-usaha untuk memperbaiki keadaan Penjara di Eropah terus-menerus dilakukan. Pada tahun 1790 Jeremy Bentham merencanakan suatu rumah penjara dengan sel yang beratap kaca dengan tembok menghadap suatu pusat dimana para penjaga di tempatkan. Sistem pemidanaan terus dipermasalahkan oleh para ahli,sampai kini pun belum pernah ada yang memuaskan secara sempurna.Penjurusan pandangan akhirnya terjadi pada permulaan abad ke-19 dengan munculnya dua pandangan yang saling bertentangan tentang filsafat pemidanaan.

Berbicara tentang ide dasar “

Double Track Systeem" bermakna berbicara tentang gagasan dasar mengenai Sistem Sanksi yang menjadi dasar kebijakan dan penggunaan Sanksi dalam hukum pidana. Dalam hal ini sistem dua jalur mengenai Sanksi dalam hukum pidana.ide dasar system ini adalah " Kesetaraan Antara Sanksi Pidana Dan Sanksi Tindakan “. Ide kesetaraan ini dapat ditelusuri lewat perkembangan yang terjadi dalam sistem sanksi hukum pidana dari aliran Klasik ke Aliran Modern dan Aliran Neo Klasik. Aliran klasik pada prinsipnya hanya menganut “ Single Track System " yakni sistem sanksi tunggal berupa jenis sanksi pidana.Berkaitan hal tersebut Sudarto mengatakan bahwa aliran klasik tentang pidana bersifat retributif dan refresif terhadap tindak pidana. Aliran ini muncul pada abad XVIII yang berpaham indeterminisme mengenai kebebasan kehendak manusia yang menekankan perbuatan pelaku kejahatan sehingga dikehendakilah hukum pidana perbuatan.Sistem pidana dan pemidanaan aliran klasik ini sangat menekankan pemidanaan terhadap perbuatan bukan kepada pelakunya.

Pada abad XIX lahirlah aliran modren yang mencari sebab kejahatan dengan memakai metode ilmu alam dan bermaksud untuk langsung mendekati atau mempengaruhi penjahat secara positif sejauh dia masih dapat diperbaiki. Aliran modren memandang kebebasan kehendak manusia bsnyak dipengaruhi oleh watak dan lingkungannya sehingga tidak dapat dipersalahkan dan dipidana. Sebagai konsekuensi dari ide " Individualisasi Pidana" maka sistem pemidanaan dalam hukum pidana modren pada gilirannya berorientasi kepada pelaku dan perbuatan .Jenis sanksi yang ditetapkan tidak hanya meliputi sanksi pidana,tetapi juga sanksi tindakan.Pengakuan tentang kesetaraan antara Sanksi Pidana dan sanksi Tindakan yang merupakan hakikat asasi atau ide dasar dari "Konsep Double Track System ".

Double track system adalah kedua-duanya,yakni sanksi pidana dan sanksi tindakan. Doble track system tidak sepenuhnya memakai satu diantara dua jenis sanksi itu. Sistem dua jalur ini menempatkan dua jenis sanksi tersebut dalam kedudukan yang setara.Penekananya pada kesetaraan sanksi pidana dan sanksi tindakan dalam kerangka double track system. Sesungguhnya terkait dengan fakta bahwa unsur pencelaan/penderitaan (lewat sanksi 
Pidana) dan unsur pembinaan (lewat sanksi tindakan) sama-sama penting. Perbedaan Sanksi Pidana Dan Sanksi Tindakan

1. Sanksi Pidana bersumber pada ide dasar "Mengapa diadakan pemidanaan" Sanksi Tindakan bertolak dari ide dasar " Untuk apa diadakan Pemidanaan itu"

2. Sanksi Pidana sesungguhnya bersifat reaktif terhadap suatu perbuatan. Sanksi Tindakan lebih bersifat antipatif terhadap pelaku perbuatan tersebut.

3. Sanksi Pidana lebih menekankan kepada unsur pembalasan .Ia merupakan penderitaan yang sengaja dibebankan kepada yang melakukan kejahatan Sanksi Tindakan menekankan kepada ide dasar perlindungan masyarakat dan pembinaan atau perawatan kepada sipembuat.

4. Sanksi Pidana dititikberatkan pada pidana yang diterapkan untuk kejahatan yang dilakukan. Sanksi Tindakan mempunyai tujuan yang bersifat sosial.

Double track system menghendaki adanya unsur pencelaan/penderitaan dan unsur pembinaan sama-sama diakomodasi dalam sistem sanksi hukum pidana.Inilah yang menjadi dasar penjelasan mengapa dalam double track system dituntut adanya kesetaraan antara Sanksi Pidana dan sanksi tindakan hal ini bisa diterapkan bagi pelaku penyalahgunaan narkotika sehingga efek jera dan proses penyembuhan dari pelaku kejahatan narkotika tersebut dapat berjalan sebagaimana yang diharapkan.

\section{KESIMPULAN}

Ide Double Track System dituntut adanya kesetaraan antara Sanksi Pidana dan sanksi tindakan hal ini bisa diterapkan bagi pelaku penyalahgunaan narkotika sehingga efek jera dan proses penyembuhan dari pelaku kejahatan narkotika tersebut dapat berjalan, sehingga bagi para pelaku kejahatan narkotika dan dengan proses ini dilksanakan akan mampu untuk sembuh dari ketergantungan penggunaan Narkotika dan jera karena adanya sanksi pidana

\section{DAFTAR PUSTAKA}

Aziz Syamsuddin,2011,Tindak Pidana Khusus,Sinar Grafika Jakarta.

Adam Chazawi,2002Pelajaran Hukum Pidana I (Stelsel Pidana,Tindak Pidana,Teori-teori Pemidanaan,Batas Berlakunya Hukum Pidana),PT.Grafindo Persada Jakarta.

Andi Hamzah, 1986, Sistem Pidana Dan Pemidanaan Indonesia Dari Retbusi Ke Reformasi,Pradnya Paramita Jakarta.

Achmad Ali,2008,Menguak Realitas Hukum (Rampai kolom dan artikel pilihan dalam bidang hukum),Prenada Media Group Jakarta.

Bambang Waluyo,2000,Pidana Dan pemidanaan,Sinar Grafika.

Barda Nawawi Arief,2011,Kebijakan Hukum Pidana Perkembangan Penyusunan Konsep KUHP Baru,Kencana Prenada Group.

Eva Achjani Zulfa,2010,Pergeseran Paradigma Pemidanaan,Lubuk Agung Bandung

Leden Marpaung,2005,Tindak Pidana Terhadap Nyawa Dan Tubuh,Sinar Grafika Jakarta. 
Lamintang, 1997,Dasar-dasar Hukum Pidana Indonesia,PT.Aditya Bakti Bandung.

Majda

Muhtaj,2005,Konstitusionalitas Hukuman Mati Di Indonesia..

Nelvitia Purba,2003,Perkembangan Konsep Pidana Mati Di Indonesia,Pascasarjana Univ.Sumatera Utara

Nelvitia Purba,Sri

Sulistyawati,2015,Mengenal lebih Dekat Hukum Pidana Dalam Perspektif Hukum Di Indonesia, CV.Citra Mandiri.

R.Soesilo,1983,Kitab UndangUndang Hukum Pidana (KUHPidana) Serta Komentarnya Pasal Demi Pasal,Politea Bogor.

Sholehuddin,Sistem Sanksi Dalam

Hukum Pidana (Ide Dasar Double Track System Dan Implementasinya,Rajawali Pers Jakarta,2003.Hlm.24

Sudarto,1974,Suatu Dilemma Dalam Pembaharuan Sistem Pidana Indonesia,Pidato Pengukuhan Jabatan Guru Besar Hukum Pidana Pada Fakultas Hukum Universitas Diponegoro,Semarang.

SR.Sianturi,2002,Asas-Asas Hukum Pidana Di Indonesia Dan Penerapannya,Storia Grafika Jakarta.

Utrecht,1960,Hukum Pidana I,Universitas Indonesia.

Bunga Reh BR PA.Skripsi : Perpektif Kriminologi Tentang penyalahgunaan Narkotika di Kota Binjai Fak.Hukum USU Medan,2002.

Badan Narkotika Nasional,Buku Bacaan Bagi Pelajar SMA Kampanye Anti Narkoba.
Direktorat Bimbingan Masyarakat POLRI,Penanggulangan

Penyalahgunaan Bahaya Narkoba,2001.

Joko Subagyo,Metode Penelitian Dalam Teori Dan Praktek,Rineka Cipta,2011.

Lexy Moleong,Metodologi Penelitian Kualitatif,PT.Remaja Rosdakarya Bandung,2005.

Maidin Gultom,Perlindungan Hukum Terhadap Anak Dan Perempuan,Refika

Aditama,2012.

Makarao, M.Taufik, Suhasril dan H.M.Zakky A.S.,Tindak Pidana Narkotika,Ghalia Indonesia Jakarta,2005.

Mastar Ain Tanjong,Pahami Kejahatan Narkoba,Letupan Indonesia Jakarta,2004.

Marlina,Peradilan Pidana Anak Indonesia Pengembangan Konsep Diversi Dan Restorative Justice, 2009.

Peter Mahmud Marzuki,Penelitian Hukum,Kencana Prenada Media Group Jakarta,2011

Sugiyono,Metode Penelitian Kuantatif Kualitatif Dan R \& D,Alpabeta, 2011.

Sugiyono,Statistika Untuk Penelitian,Alfabeta,2011

Sudarsono,Kenakalan

Remaja,Rineka

Cipta

Jakarta,1991.

Supramono,Hukum Narkoba di Indonesia,Djambatan

Jakarta,2004.

Sutrisno Hadi,Metodologi Research,Andi,Yogyakarta,2000.

Ulber Silalahi,Metode Penelitian Sosial,Refika Aditama,2009.

Waluyo Bambang,Pidana Dan Pemidanaan,Sinar Grafika Jakarta,2004.

Bahan Hukum Tertier 
Anwar Desy, Kamus Lengkap

Bahasa

Indonesia,Amelia,Surabaya,2003

Kejaksaan Agung Republik Indonesia,Peristilahan Hukum Di Dalam Praktek, 1985.

Kitab Undang-Undang Hukum Pidana

Undang-Undang Nomor 22 Tahun 1997 Tentang Narkotika. 